\title{
МЕТОДИКА ВИКОРИСТАННЯ ЦИФРОВИХ ОСВІТНІХ РЕСУРСІВ У ПРОЦЕСІ ПІДГОТОВКИ МАЙБУТНІХ УЧИТЕЛІВ ІНФОРМАТИКИ
}

\section{Світлана Яцюк}

кандидат педагогічних наук, доцент кафедри загальної математики та методики навчання інформатики Волинський національний університет імені Лесі Українки

м. Луцьк, Україна

ORCID ID 0000-0002-8369-6060

Yatsyuk.Svitlana@vnu.edu.ua

\section{Марія Хомяк}

кандидат фізико-математичних наук,

доцент кафедри загальної математики та методики навчання інформатики Волинський національний університет імені Лесі Українки

м. Луцьк, Україна

khomyak.maria@vnu.edu.ua

\section{Валентина Юнчик}

старший викладач кафедри

загальної математики та методики навчання інформатики

Волинський національний університет імені Лесі Українки

м. Луцьк, Україна

ORCID ID 0000-0003-3500-1508

Yunchyk.Valentyna@vnu.edu.ua

\section{Тетяна Чепрасова}

кандидат педагогічних наук,

доцент кафедри загальної математики та методики навчання інформатики Волинський національний університет імені Лесі Українки

м. Луцьк, Україна

ORCID ID 0000-0002-0035-5106

cheprasova.tatiana@vnu.edu.ua

Анотація. У дослідженні проаналізовано значення цифрових освітніх ресурсів, завдяки яким можна підвищувати якість навчально-виховного процесу та розв'язувати професійні задачі. Досліджено нормативні документи щодо використання цифрових освітніх ресурсів, а також питання державних стандартів повної загальної середньої освіти, які надають перевагу саме інформаційно-комунікаційній компетентності, в якій цифрова компетентність визнана ключовою. Зроблено аналіз літературних вітчизняних та закордонних джерел щодо тематики дослідження. Окреслено методику використання цифрових освітніх ресурсів майбутніми вчителями інформатики, розглянуто різні підходи щодо питань використання та створення цифрових освітніх ресурсів під час вивчення інформативних дисциплін. Висвітлено задачі, які

Професіоналізм педагога: теоретичні й методичні аспекти. - Вип. 16. - Слов’янськ, 2021. 


\section{С. ЯЦЮК, М. ХОМЯК, В. ЮНЧИК, Т. ЧЕПРАСОВА \\ Методика використання цифрових освітніх ресурсів у процесі підготовки майбутніх учителів інформатики}

необхідно виконувати вчителю для розвитку навчально-пізнавальної діяльності учнів. Розглянуто методику викладання курсу «Цифрові технології наукових досліджень в галузі освіти/педагогіки», проведено характеристику основних компетентностей майбутніх учителів в результаті вивчення даного курсу. Висвітлено методичну ціль читання лекцій, однією з яких є пізнавальна активність студентів, зацікавленість до навчального предмету та науки. Зроблено акцент на використанні спеціального обладнання при читанні лекцій та виконанні лабораторних робіт. Зроблено висновки та перспективи подальших досліджень. діяльність.

Ключові слова: освітні ресурси; освіта; вчитель; компетентність; професійна

Постановка проблеми в загальному вигляді. Використання цифрових освітніх ресурсів постійно зростає з року в рік, особливо у сфері освіти. Увага освітян до використання цифрових технологій пояснюється зручністю, простотою використання їх у своїй професійній діяльності. Адже це значно підвищує якість навчально-виховного процесу, індивідуальну діяльність учнів.

У своїй роботі вчитель знаходиться у постійному пошуку освітніх цифрових ресурсів (Войтович, 2017; Гуржій, 2013). Час вимагає аналізу їх на доцільність використання та створення своїх власних освітніх ресурсів. Вчителя інформатики це стосується в першу чергу, оскільки його професійна діяльність напряму пов'язана 3 використанням цифрових інформаційних ресурсів. Тому підготувати конкурентоспроможного фахівця, який би ефективно використовував цифрові освітні ресурси в тій чи іншій галузі знань, вирішувати завдання за допомогою інтерактивних технологій - важливе завдання закладів вищої освіти (Гаврілова, 2017; Гуржій, 2013).

Аналіз останніх досліджень і публікацій. Аналіз літературних джерел показав, що проблемам впровадження цифрових ресурсів в освітній процес приділяли увагу такі вчені як В. Биков, Н. Морзе, А. Кочарян, А. Гужій, В. Лапінський, О. Колгатін, Л. Колгатіна, М. Шишкіна, Н. Войтович, С. Семеріков, О. Спірін, Л. Гаврілова, Я. Топольник, С. Соловйов. Учені підкреслювали важливість розвитку усіх галузей освіти, вагомість яких змінюється з розвитком і використанням освітніх цифрових ресурсів.

Аналіз літературних джерел дає змогу констатувати, що використання сучасних цифрових освітніх ресурсів в освітній діяльності $\epsilon$ важливою передумовою успішної професійної і наукової діяльності, тому існує реальна потреба у вдосконаленні змісту освіти майбутніх учителів інформатики та розробці методики використання цифрових освітніх ресурсів.

Формулювання цілей статті (постановка завдання). Мета дослідження полягає у висвітленні значення та методики використання сучасних цифрових освітніх ресурсів у процесі підготовці вчителів інформатики.

Результати дослідження. Законом України «Про освіту» визнано 
інформаційно-комунікаційну компетентність як одну із важливих, яка необхідна сучасній людині для успішної життєдіяльності. Державною стратегією регіонального розвитку на 2021-2027 роки, затвердженою Кабінетом Міністрів України від 5 серпня 2020 р. № 695 (Офіційний вісник України, 2020 р., № 67, ст. 2155) визнано низький рівень цифровізації регіонів і цифрової обізнаності. Державний стандарт базової середньої освіти, затверджений постановою Кабінетом Міністрів України від 30 вересня 2020 р. № 898 «Про деякі питання державних стандартів повної загальної середньої освіти» (Офіційний вісник України, 2020 р., № 81, ст. 2615) визначає інформаційно-комунікаційну компетентність такою, що передбачає впевнене, критичне і відповідальне використання цифрових технологій для власного розвитку і спілкування, здатність безпечно використовувати цифрові технології в навчанні, дотримуючись принципів академічної доброчесності.

Досвід європейських країн свідчить про суттєвий вплив здійснених заходів щодо цифрових компетентностей населення на розвиток економіки та конкурентоспроможність країн $Є С$ на міжнародному рівні. Так, Європейський парламент і Рада СС 22 травня 2018 року ухвалили рамкову програму оновлених ключових компетентностей для навчання впродовж життя, в якій цифрова компетентність визнана однією з восьми ключових.

Цифрові освітні ресурси відіграють надзвичайно важливу роль в організації навчально-пізнавальної діяльності учнів (Bykov, 2016; Войтович, 2017; Гуржій, 2013).

Для підтримки та розвитку навчально-пізнавальної діяльності учнів учителю необхідно виконувати наступні задачі:

- здійснювати пошук наявних цифрових ресурсів;

- аналізувати та здійснювати добір цифрових освітніх ресурсів;

- моделювати та створювати власні цифрові ресурси;

- вміти користуватись мультимедійними та мережевими цифровими ресурсами;

- використовувати цифрові ресурси у навчальному процесі і створенні проєктів.

Для розв'язання цих задач необхідно сформувати у майбутнього вчителя уміння і навички використання і створення цифрових освітніх ресурсів (Bykov \& Leshchenko, 2016).

При вивченні курсу «Цифрові технології наукових досліджень в галузі освіти/педагогіки» у студентів формуються теоретичні знання і практичні навички щодо ефективного використання сучасних цифрових технологій в 


\section{С. ЯЦЮК, М. ХОМЯК, В. ЮНЧИК, Т. ЧЕПРАСОВА \\ Методика використання цифрових освітніх ресурсів у процесі підготовки майбутніх учителів інформатики}

науковій, організаційній, методичній та навчально-виховній складових професійноїдіяльності майбутнього вчителя. Даний курс викладається протягом семестру і має на меті розглянути теоретичні знання та практичні навички 3 оволодіння цифровими технологіями наукових досліджень в галузі освіти/педагогіки. Добір змісту курсу має прикладну, практичну спрямованість навчання. Лекційний курс спрямований на розвиток пізнавальної активності студентів. Тому викладач повинен послідовно, доступно викладати матеріал із використанням сучасного обладнання. Наприклад, використовуючи відеометод, викладач перетворює класичну лекцію в лекцію-візуалізацію, що дає змогу реалізувати принцип наочності.

Курс розбито на відповідні модулі та теми:

1. Цифрові ресурси в інформаційному суспільстві.

2. Цифрові інформаційні ресурси у галузі освіти.

3. Мультимедійні цифрові ресурси з мережевим доступом.

4. Вітчизняні та закордонні колекції ЦОР.

5. Системний підхід до створення та використання ЦОР.

6. Технології педагогічного проектування ЦОР.

7. Мультимедійна інформація та людина.

8. Оптимізація цифрових мультимедійних ресурсів для мережевого середовища.

9. Інформатизація освіти і науки.

10. Розвиток електронної освіти в Україні і у світі. Історія, тенденції, перспективи.

11. Базова модель процесу наукового дослідження.

12. Застосування інтерактивних технологій в електронних освітніх pecypcax.

13. Хмарні технології для інформатизації освіти.

14. Розробка електронних освітніх ресурсів.

15. Розробка сценаріїв навчальних занять, 3 використанням засобів інформатизації освіти.

Під час розроблення методики використання цифрових освітніх ресурсів в процесі підготовки майбутніх учителів інформатики, слід приділяти увагу вибору методів навчання:

- пояснювально-ілюстративні (найбільшої уваги заслуговує принцип наочності): студент пасивно засвоює матеріал;

- репродуктивні: відтворення навчальних дій за раніше визначеним алгоритмом, повторення та закріплення пройденого матеріалу; 


\section{С. ЯЦЮК, М. ХОМЯК, В. ЮНЧИК, Т. ЧЕПРАСОВА \\ Методика використання цифрових освітніх ресурсів у процесі підготовки майбутніх учителів інформатики}

- проблемний виклад навчального матеріалу: викладач ставить питання і будує своє повідомлення як відповідь;

- частково-пошукові: самостійна діяльність студента під керівництвом викладача;

- д дослідницькі (можна віднести метод проєктів - поєднуються з груповою та індивідуальною формами організації самостійної діяльності студентів): організація самостійної діяльності з врахуванням освітніх потреб;

- демонстраційних прикладів (використовувати програму запису екрану): демонстрація виконаних завдань.

Важливим є співвідношення лекцій і практичних занять: 1 до 1. Основними формами практичних занять є лабораторні заняття. Методика проведення лабораторних робіт розрахована на самостійну роботу студента, а саме на пошук та опрацювання літературних джерел, отримання нових знань на основі набутих старих, розв'язування прикладних задач, застосування знань у своїй професійній діяльності та науковій сфері, розв'язуванням завдань розвитку професійної діяльності, поєднання наукового пошуку з навчальною діяльністю, пошук i прогнозування нових форм роботи. При виконанні лабораторних робіт використовуються такі форми:

- фронтальні, використовуються спільні задачі для всієї групи;

- групові, різні задачі виконуються окремими групами студентів;

- індивідуальні, кожен студент отримує індивідуальне завдання;

- колективні.

Як показує дослідження якість проведення лабораторних занять 3 використанням фронтальної форми є менш ефективною, ніж індивідуальні, колективні чи групові. Вчитель інформатики повинен сам організовувати творчу роботу учнів на уроках. Тому лабораторні роботи краще виконувати 3 використанням колективної чи групової форми роботи.

Впровадження методики використання цифрових освітніх технологій в наукових дослідженнях передбачає використання форм дистанційного навчання: чат-заняття, веб-семінари (Соловйов, 2015; Колгатін, 2012; Спірін, 2013). Для проведення семінарів використовується форум сайту Освітні веб-ресурси, який дає змогу проводити заняття за визначеними темами на протязі усього семестру.

Використання цифрових освітніх ресурсів дає змогу проводити миттєву перевірку виконаних студентами лабораторних робіт, що дає в першу чергу мотивацію студентам, а викладачу - економію часу.

При проведенні лабораторних та лекційних занять використовуються засоби навчання (як матеріальні, так і ідеальні об’єкти, які використовуються в

Професіоналізм педагога: теоретичні й методичні аспекти. - Вип. 16. - Слов’янськ, 2021. 
освітньому процесі). Їх можна поділити на традиційні і засоби нових інформаційно-комунікаційних технологій (Колгатін, 2012; Шишкіна, 2016). Прикладами таких засобів можуть служити:

1. Відкритий клас. Мережеві освітні спільноти. Це проєкт для розвитку електронних освітніх Інтернет-ресурсів нового покоління, включаючи культурно-пізнавальні сервіси, систем дистанційного загального і професійного навчання(e-learning), у тому числі для використання людьми 3 обмеженими можливостями. Цей проєкт спрямований на забезпечення нової якості освіти за рахунок створення соціально-педагогічних спільнот в мережі Інтернет, діяльність яких спрямована на вирішення комплексних завдань:підтримка процесів інформатизації шкіл; професійний розвиток педагогів у сфері ІКТ; широке поширення електронних освітніх ресурсів та впровадження методик використання; модернізація системи методичної підтримки інформатизації освіти.

2. Методичний портал. Це спеціалізований ресурс призначений для вчителів, співавтором якого може бути будь-який користувач. Головна мета проєкту не кількість інформації, а максимальна користь від неї.

Відмінність цього ресурсу від аналогічних:

- категоризація матеріалів - глибока, багаторівнева;

- зручність пошуку - меню праворуч;

- тематичність - виключно для вчителів;

- нічого зайвого - тільки найкраще і найнеобхідніше;

- справедливість - отримав допомогу - допоможи іншим;

- безкоштовність - платою за чиюсь допомогу може бути тільки допомога іншому;

- потужна платформа, яка дозволить розвивати та вдосконалювати проект (але не ускладнювати).

При використанні матеріалів сайту обов'язковим є вказання авторства. Портал містить матеріали за предметами, за класами, за жанром, а також на ньому знаходяться тести та бібліотека.

3. Національний проєкт «Відкритий світ» (Рис. 1). Це проєкт освіти майбутнього. Проєкт запроваджують для створення нової системи шкільної освіти з потужним використанням новітніх інформаційних технологій, яка зможе виховати спеціалістів нового покоління - 3 високим рівнем знань, технічно освічених і конкурентних на світовому ринку. 


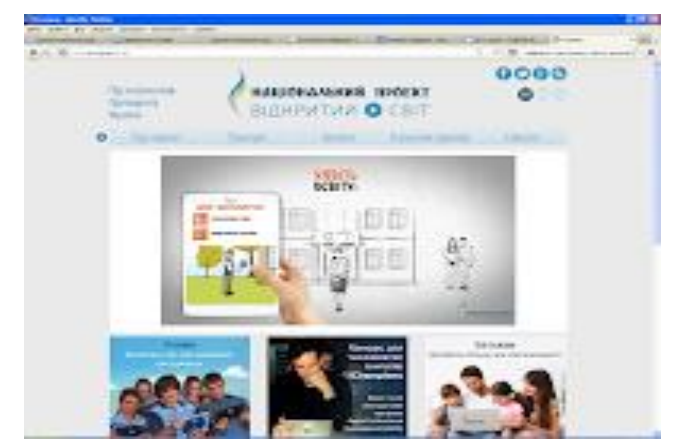

Рис. 1. Вікно сайту «Відкритий світ»

4. Інститут ЮНЕСКО з ІТ в освіті. Місія IITO (Рис. 2).

Служить центром передового досвіду і покликаний надавати технічне сприяння і консультації у сфері застосування ІКТ в освіті.

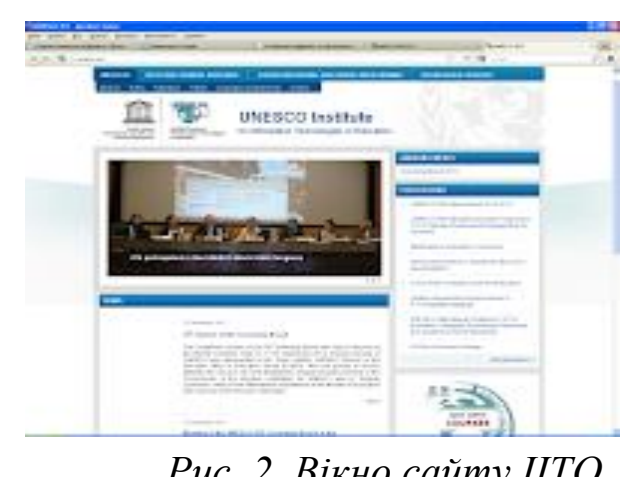

Pис. 2. Вікно сайту IITO

У рамках свого статусу і функцій IITО сприяє ЮНЕСКО, концентруючи зусилля на наступних напрямках :

- ліквідація цифрового розриву в освіті;

- створення інклюзивних товариств знань шляхом зміцнення національного потенціалу з розвитку електронних технологій для розширення доступу до освіти та навчання протягом усього життя;

- організації політичного діалогу;

- розробки національних стратегій щодо застосування IКТ в освіті.

Висновки 3 дослідження і перспективи подальших розвідок у цьому напрямі. У роботі висвітлено нове вирішення проблеми створення методики використання цифрових освітніх ресурсів у процесі підготовки вчителів інформатики. У ході дослідження отримано такі результати:

1. Проведено аналіз літературних джерел та визначено основні професійні вимоги до використання вчителем інформатики цифрових освітніх технологій в науковій та навчально-виховній діяльності. 


\section{С. ЯЦЮК, М. ХОМЯК, В. ЮНЧИК, Т. ЧЕПРАСОВА \\ Методика використання цифрових освітніх ресурсів у процесі підготовки майбутніх учителів інформатики}

2. Визначено практичне застосування цифрових освітніх технологій при вивченні інформативних дисциплін, які передбачені освітньо-професійними програмами.

3. Розроблено методику використання цифрових освітніх технологій в процесі підготовки вчителів інформатики.

4. Розроблено курс «Цифрові технології наукових досліджень в галузі освіти/педагогіки»

5. Запропоновано засоби навчання ЦОР майбутніх вчителів інформатики.

Отримані результати дають підставу зробити наступні висновки :

1. На даному етапі розвитку суспільства, освіти важливого значення набуває впровадження цифрових освітніх технологій та їх ефективне застосування в навчальному процесі.

2. Використання цифрових освітніх ресурсів дає змогу формувати інформаційно-пошукові вміння, що відбувається безпосередньо під час роботи 3 цифровими освітніми ресурсами.

3. Методика використання цифрових освітніх ресурсів повинна бути спрямована на точний відбір майбутніми вчителями інформатики цифрових освітніх ресурсів і використання їх у своїй професійній діяльності для отримання результату.

4. Підготовка до використання цифрових освітніх ресурсів вчителями інформатики повинна бути наскрізною і здійснюватись як в процесі вивчення інформативних дисциплін, так і при введенні інших спецкурсів чи дисциплін.

5. Системне, цілеспрямоване використання цифрових освітніх ресурсів при вивченні інформативних дисциплін дає змогу поглибити розуміння студентами навчального матеріалу, посилити мотивацію навчання, надати йому творчого, дослідницького характеру.

6. Використання засобів навчання дозволить організовувати колективну та групову роботи під час виконання лабораторних занять, обговорювати результати роботи та самостійного опрацювання навчального матеріалу.

Перспективу подальших досліджень вбачаємо у можливості використовувати в освітньому процесі нові, більш масштабні освітні цифрові ресурси.

\section{СПИСОК ВИКОРИСТАНИХ ДЖЕРЕЛ}

1. Bykov, V. Yu., i Leshchenko, M. P. (2016). Digital humanistic pedagogy: relevant problems of scientific reseach in the field of using ict in education. Information Technologies and Learning Tools, 53 (3), 1 - 17.

2. Войтович, Н. В. і Найдьонова, Н. В. (2017). Використання хмарних технологій Google ma сервісів web 2.0 в освітньому прочесі. Дніпро, Україна: Вид-во ДПТНЗ 
«Дніпровський центр ПТОТС».

3. Гаврілова, Л. Г. і Топольник, Я. В. (2017). Цифрова культура, цифрова грамотність, цифрова компетентність як сучасні освітні феномени. Інформаційні технологї $i$ засоби навчання, 61 (5), 1-14.

4. Гуржій, А. М. і Лапінський, В.В. (2013). Електронні освітні ресурси як основа сучасного навчального середовища загальноосвітніх навчальних закладів. Інформаційні технології в освіті, 15, 30-37.

5. Інтеграція України в Свропейський інформаційний простір: виклики та завдання. (2016). Київ: Вид-во ФОП Клименко.

6. Соловйов, С. Г. (2015). Інформаційна складова державної політики та управління. Київ, Україна: К.І.С.

7. Концепція розвитку цифрових компетентностей 2021-2027 років. (2020). Офіційний вісник України.

8. Колгатін, О. Г. і Колгатіна, Л. Г. (2012). Навчання майбутніх учителів застосуванню інформаційних технологій в психолого-педагогічних дослідженнях. Засоби навчальної та науково-дослідної роботи, 39, 45-51.

9. Спірін, О. М. (2013). Методична система базової підготовки вчителя інформатики за кредитномодульною технологією. Житомир, Україна: Вид-во ЖДУ ім. І. Франка.

10. Шишкіна, М. П. (2016). Теоретико-методичні засади формування $i$ розвитку хмарно-орієнтованого освітньо-наукового середовища вищого навчального закладу. (Дис. канд. наук). Київ, Україна: Ін-т інформац. технолог. і засобів навч. НАПН України.

\title{
METHODOLOGY OF USING DIGITAL EDUCATIONAL RESOURCES IN THE PROCESS OF TRAINING FUTURE TEACHERS OF INFORMATICS
}

\author{
Svitlana Yatsiuk \\ Candidate of Pedagogical Sciences, \\ Associate Professor Department of General Mathematics \\ and Methods of Teaching Computer Science \\ Lesya Ukrainka Volyn National University \\ Lutsk, Ukraine \\ ORCID ID 0000-0002-8369-6060 \\ Yatsyuk.Svitlana@vnu.edu.ua \\ Mariia Khomyak \\ Candidate of Physical and Mathematical Sciences, \\ Associate Professor Department of General Mathematics \\ and Methods of Teaching Computer Science \\ Lesya Ukrainka Volyn National University \\ Lutsk, Ukraine \\ khomyak.maria@vnu.edu.ua \\ Valentyna Yunchyk \\ Senior Lecturer Department of General Mathematics \\ and Methods of Teaching Computer Science
}




\title{
Lesya Ukrainka Volyn National University Lutsk, Ukraine \\ ORCID ID 0000-0003-3500-1508 \\ Yunchyk.Valentyna@vnu.edu.ua
}

\author{
Tetiana Cheprasova \\ Candidate of Pedagogical Sciences, \\ Associate Professor Department of General Mathematics \\ and Methods of Teaching Computer Science \\ Lesya Ukrainka Volyn National University \\ Lutsk, Ukraine \\ ORCID ID 0000-0002-0035-5106 \\ cheprasova.tatiana@vnu.edu.ua
}

\begin{abstract}
The study analyzes the importance of digital educational resources, which can improve the quality of the educational process and solve professional problems. The normative documents on the use of digital educational resources, as well as the issues of state standards of complete general secondary education, which give preference to information and communication competence, in which digital competence is recognized as key, are studied. The analysis of literary Ukrainian and foreign sources on the research topic is made.

The method of using digital educational resources by future computer science teachers is outlined, different approaches to the use and creation of digital educational resources during the study of informative disciplines are considered. The tasks that need to be performed by the teacher for the development of educational and cognitive activities of students are highlighted. The method of teaching the course "Digital technologies of scientific research in the field of education / pedagogy" is considered, the characteristic of the main competencies of future teachers as a result of studying this course is carried out. The methodical purpose of lecturing is highlighted, one of which is the cognitive activity of students, interest in the subject and science. Emphasis is placed on the use of special equipment when lecturing. The main topics of laboratory works and methods of their implementation are outlined. The study emphasizes the independent search for students and the formation of their special skills and abilities. Emphasis is placed on the forms of organization of educational activities during laboratory work and their instant verification, on individual work during laboratory work - projects where the group form of work is actively used. The method of checking the works, examining the logic of the solution, systematizing and summarizing the results of the whole group. Emphasis is placed on the use of special equipment when lecturing and performing laboratory work. Conclusions and prospects of further research are made.
\end{abstract}

Key words: educational resources; education; the teacher; competence; professional activity.

\section{REFERENCES}

1. Bykov, V. Yu., \& Leshchenko, M. P. (2016). Digital humanistic pedagogy: relevant problems of scientific reseach in the field of using ICT in education. Information Technologies and Learning Tools, 53 (3), 1 - 17. [in English].

2. Voitovych, N. V. \& Naidonova, N. V. (2017). Vykorystannia khmarnykh tekhnnolohii Google ta servisiv web 2.0 v osvitnomu protsesi [Use of Google cloud technologies and web 2.0 services in the educational process]. Dnipro, Ukraine: Dniprovsky Center PTOTS Publishing House. [in Ukrainian].

3. Havrilova, L. H. \& Topolnyk, Ya. V. (2017). Tsyfrova kultura, tsyfrova hramotnist, 


\section{С. ЯЦЮК, М. ХОМЯК, В. ЮНЧИК, Т. ЧЕПРАСОВА \\ Методика використання цифрових освітніх ресурсів у процесі підготовки майбутніх учителів інформатики}

tsyfrova kompetentnist yak suchasni osvitni fenomeny. [Digital culture, digital literacy, digital competence as modern educational phenomena]. Information Technologies and Learning Tools, 61 (5), 1-14. [in Ukrainian].

4. Hurzhii, A. M. \& Lapinskyi, V. V. (2013). Elektronni osvitni resursy yak osnova suchasnoho navchalnoho seredovyshcha zahalnoosvitnikh navchalnykh zakladiv [Electronic educational resources as the basis of the modern educational environment of secondary schools]. Information Technologies in Education, 15, 30-37. [in Ukrainian].

5. Intehratsiia Ukrainy $\mathrm{v}$ Yevropeiskyi informatsiinyi prostir: vyklyky ta zavdannia [Integration of Ukraine into the European information space: challenges and tasks]. (2016). Kyiv: FOP Klymenko Publishing House. [in Ukrainian].

6. Soloviov, S. H. (2015). Informatsiina skladova derzhavnoi polityky ta upravlinnia [Information component of the state policy and management]. Kyiv, Ukraine: K.I.S. [in Ukrainian].

7. The concept of digital competencies development in 2021-2027. (2020). Official Gazette of Ukraine. [in Ukrainian].

8. Kolhatin, O. H. \& Kolhatina, L. H. (2012). Navchannia maibutnikh uchyteliv zastosuvanniu informatsiinykh tekhnolohii $\mathrm{V}$ psykholoho-pedahohichnykh doslidzhenniakh [Teaching future teachers to use information technology in psychological and pedagogical research]. Means of educational and research work, 39, 45-51. [in Ukrainian].

9. Spirin, O. M. (2013). Metodychna systema bazovoi pidhotovky vchytelia informatyky za kredytnomodulnoiu tekhnolohiieiu [Methodical system of basic training of computer science teachers on credit-module technology]. Zhytomyr, Ukraine: ZhSU Publishing House. I. Franko. [in Ukrainian].

10.Shyshkina, M. P. (2016). Teoretyko-metodychni zasady formuvannia i rozvytku khmarnooriientovanoho osvitno-naukovoho seredovyshcha vyshchoho navchalnoho zakladu [Theoretical and methodological principles of formation and development of cloud-oriented educational and scientific environment of higher education]. (PhD dissertation). Kyiv, Ukraine: Inst. technologist. and teaching aids. NAPS of Ukraine. [in Ukrainian].

Матеріали надійшли до редакції 14.09.2021 p.

Професіоналізм педагога: теоретичні й методичні аспекти. - Вип. 16. - Слов’янськ, 2021. 